Roczniki Administracji i Prawa nr XVIII(1), s. 355-365

\title{
Artykuł przeglądowy
}

\section{Reviev article}

Data wpływu/Received: 25.01.2018

Data recenzji/Accepted: 24.04.2018

Data publikacji/Published: $\mathbf{3 0 . 0 6 . 2 0 1 8}$

Źródła finansowania publikacji: środki własne Autora

\section{DOI: 10.5604/01.3001.0012.6008}

Authors' Contribution:
(A) Study Design (projekt badania)
(B) Data Collection (zbieranie danych)
(C) Statistical Analysis (analiza statystyczna)
(D) Data Interpretation (interpretacja danych)
(E) Manuscript Preparation (redagowanie opracowania)
(F) Literature Search (badania literaturowe)

Paula Nowak ${ }^{*}$

\section{OUTSOURCING - PRÓBA ODNALEZIENIA DEFINICJI POJĘCIA NA GRUNCIE POLSKIEGO PRAWA PRACY}

\section{WSTĘP}

Outsourcing to pojęcie, które w ostatnich latach zyskuje na popularności. Instytucja ta jest chętnie wykorzystywana przez pracodawców, zwłaszcza duże międzynarodowe firmy, jako sposób na wprowadzenie oszczędności przy jednoczesnej poprawie kwalifikacji personelu.

Wraz z upowszechnieniem się instytucji outsourcingu mnożą się problemy prawne związane z jej stosowaniem. Szczególnie liczne wątpliwości dotyczące tego zagadnienia powstają na gruncie prawa pracy ze względu na ogromny wpływ, jaki stosowanie outsourcingu wywiera na istniejące w jego obrębie stosunki zatrudnienia. Kwestie

\footnotetext{
* mgr; Katedra Prawa Pracy i Polityki Społecznej Uniwersytetu Jagiellońskiego.
} 
te trudno rozwiązać, gdyż dotychczas nie wypracowano jednoznacznej definicji outsourcingu, która niewątpliwie stanowiłaby punkt wyjścia dla dalszych rozważań.

Niniejsze opracowanie ma na celu dokonanie przeglądu najważniejszych istniejących definicji pojęcia outsourcingu, próbę ich usystematyzowania oraz zaproponowanie definicji najbardziej przydatnej z punktu widzenia prawa pracy.

Należy pamiętać, że choć niniejszy tekst skupia się na aspekcie prawnym outsourcingu, to jest to instytucja bardzo chętnie wykorzystywana w procesach zarządzania przedsiębiorstwami oraz zarządzania zasobami ludzkimi i w tych dziedzinach rozumiana jest zazwyczaj jako strategia biznesowa, w której przenosi się część pracy danej organizacji na partie zewnętrzne ${ }^{1}$. Z tego też względu wyjątkowo liczne są publikacje z zakresu zarządzania dotyczące outsourcingu. Wątku tego nie mogłam pominąć, a wiele $z$ prezentowanych przeze mnie poniżej definicji zostało wypracowanych właśnie na gruncie nauk związanych z zarządzaniem.

\section{ETYMOLOGIA}

Dla polskich badaczy problematyczne może się okazać już samo słowo „outsourcing". Pochodzi ono bowiem z języka angielskiego i w praktyce oraz w większości opracowań naukowych nie doczekało się polskiego odpowiednika, choć część autorów proponuje używanie w jego miejsce określenia „wydzielenie” lub „wyodrębnienie"2. Przed upowszechnieniem się pojęcia „outsourcing” popularne było stosowanie w to miejsce określenia „podwykonawstwo”, jednak wielu badaczy twierdzi, że znaczenia tych dwóch pojęć nie należy utożsamiać3.

$\mathrm{W}$ rzeczywistości nawet na gruncie języka angielskiego etymologia omawianego pojęcia nie jest jasna. Według pierwszego z poglądów słowo „outsourcing” wywodzi się wprost ze słów out, czyli „na zewnątrz” oraz source lub sourcing, czyli „źródło” lub „znajdowanie źródeł”4. Jeszcze inni uważają, że „outsourcing” to połączenie wyrazów outside, co znaczy „zewnętrzny” oraz resource, czyli „zasoby” lub „środki” Zgodnie z ostatnim poglądem termin „outsourcing” to zlepek słów outsider resources using, co da się przetłumaczyć jako „używanie zewnętrznych źródeł”6 lub „wykorzystywanie zasobów (dostaw/ środków) zewnętrznych"”. Spór ten dotyczący etymologii można zresztą potraktować jako zupełnie poboczny, ponieważ wszystkie wytłumaczenia po-

1 N. Śliwa, Bilans outsourcingu - najważniejsze korzyści i straty z wydzielenia działalności, [w:] S. Wawak, M. Sołtysik (red.), Współczesne trendy w outsourcingu, Kraków 2015, s. 39.

2 E. Marcinkowska, Outsourcing w zarządzaniu szpitalem publicznym, Warszawa 2010, s. 11.

3 P. Leighton, M. Syrett, R. Hecker, P. Holland, Nowoczesne formy zatrudnienia, Warszawa 2014, s. 46.

4 J. Marciniak, Optymalizacja zatrudnienia, wynagrodzeń i struktur organizacyjnych, Warszawa 2016, s. 173.

5 T. Naruniec, Outsourcing, [w:] J. Mioduszewski (red.), Metody organizacji i zarządzania, Olsztyn 2013, s. 251.

6 J. Foltys, Wieloaspektowy model outsourcingu na przykładzie sektora hutnictwa żelaza i stali, Katowice 2007, s. 17.

7 E. Marcinkowska, Outsourcing w zarzadzaniu..., s. 9. 
chodzenia słowa „outsourcing” dostatecznie oddają sens tej instytucji, która polega na przeniesieniu części pracy z danej organizacji na wybrany podmiot zewnętrzny ${ }^{8}$, czy też wykorzystanie zasobów i umiejętności podmiotu trzeciego na rzecz zleceniodawcy'.

\section{DEFINICJA OUTSOURCINGU}

Outsourcing nie doczekał się jednoznacznej definicji. Z tym zadaniem od wielu lat mierzą się liczni badacze. Zdecydowanie przodują $\mathrm{w}$ tym naukowcy $\mathrm{z}$ krajów anglosaskich, w których to instytucja outsourcingu cieszy się szczególną popularnością już od kilkudziesięciu lat, choć również na gruncie polskiej nauki powstało kilka interesujących definicji. Sytuacji z pewnością nie ułatwia fakt partykularnego i często niekonsekwentnego zdefiniowania pojęcia outsourcingu na gruncie przepisów prawa.

\section{W POSZUKIWANIU DEFINICJI LEGALNEJ - USTAWODAWSTWO UNIJNE I POLSKIE}

W prawodawstwie unijnym napotkać można definicje legalne pojęcia „outsourcing”. Jednakże Dyrektywa Komisji 2006/73/WE wprowadzająca środki wykonawcze do dyrektywy 2004/39/WE Parlamentu Europejskiego i Rady w odniesieniu do wymogów organizacyjnych i warunków prowadzenia działalności przez przedsiębiorstwa inwestycyjne oraz pojęć zdefiniowanych na potrzeby tejże dyrektywy ${ }^{10}$ oraz Dyrektywa Parlamentu Europejskiego i Rady 2009/138/WE w sprawie podejmowania i prowadzenia działalności ubezpieczeniowej i reasekuracyjnej (Wypłacalność II) ${ }^{11}$, które podejmują to zagadnienie, ograniczają zakres przedmiotowy zawartych w nich definicji outsourcingu wyłącznie do kontraktów, w których jedną ze stron jest odpowiednio: przedsiębiorstwo inwestycyjne, albo też zakład ubezpieczeń lub zakład reasekuracji. Z uwagi na wyraźnie ograniczony zakres podmiotowy definicji outsourcingu zawartych w wyżej wymienionych aktach prawnych i ich wyraźnie partykularny charakter, definiujący termin „outsourcing” jedynie na potrzeby danej regulacji, definicje te, naświetlając wyłącznie kwestię outsourcingu w wąskich gałęziach rynku, okazują się nieprzydatne do celu skonstruowania ogólnej definicji tego pojęcia.

Podobnie na gruncie polskiego systemu prawa brak jest ogólnej definicji pojęcia „outsourcing”, choć sam termin pojawia się kilkakrotnie. W ustawie o działalności

\footnotetext{
N. Śliwa, Bilans outsourcingu..., s. 39.

9 A. Korzeniowska, Klasyfikacje outsourcingu, „Annales Universitatis Mariae Curie-Skłodowska” 2009, sectio H, vol. XLIII, 17, s. 277, http://annales.umcs.lublin.pl/annales_ekonomia.php [dostęp: 1.12.2017]. 10 Z dnia 10 sierpnia 2006 roku, Dz.U.UE.L.2006.241.26, http://eur-lex.europa.eu/legal-content/PL/ TXT/PDF/?uri=CELEX:32006L0073\&qid=1510496796255\&from=PL [dostęp: 1.12.2017].

11 Z dnia 29 listopada 2009 roku, Dz.U.UE.L.2009.335.1, http://eur-lex.europa.eu/legal-content/PL/ TXT/PDF/?uri=CELEX:32009L0138\&qid=1510497157672\&from=PL [dostęp: 1.12.2017].
} 
ubezpieczeniowej i reasekuracyjnej znaleźć można przepis, zgodne z którym outsourcing oznacza „umowę między zakładem ubezpieczeń albo zakładem reasekuracji a dostawcą usług, na podstawie której dostawca usług wykonuje proces, usługę lub działanie, które w innym przypadku zostałyby wykonane przez zakład ubezpieczeń lub zakład reasekuracji, a także umowę, na podstawie której dostawca usług powierza wykonanie takiego procesu, usługi lub działania innym podmiotom, za pośrednictwem których wykonuje on dany proces, usługę lub działanie"12. Jak nietrudno zauważyć, definicja ta została skonstruowana w sposób podobny do wyżej omawianych przykładów z prawa unijnego i ma zastosowanie tylko do wąskiego zakresu objętego regulacją ustawy, w której się znajduje. Nie można więc traktować jej jako definicji outsourcingu w polskim systemie prawa in genere.

Termin „outsourcing” pojawia się także w rozporząazzeniu Rady Ministrów w sprawie Polskiej Klasyfikacji Działalności (PKD). Według niego outsourcing, czyli zlecenie wykonania usług na zewnątrz to „kontrakt, zgodnie z którym zleceniodawca wymaga od zleceniobiorcy wykonania określonego zadania, np. części lub całego procesu produkcyjnego, usług związanych z zatrudnieniem lub usług pomocniczy$\mathrm{ch}^{\prime \prime 3}$. Niemalże tożsama definicja outsourcingu znajduje się w rozporządzeniu Rady Ministrów w sprawie Polskiej Klasyfikacji Wyrobów i Usług (PKWiU) ${ }^{14}$. Taki sposób określenia pojęcia „outsourcing”, choć bez wątpienia mający zastosowanie do szerszej grupy sytuacji niż przytoczona uprzednio definicja z ustawy o działalności ubezpieczeniowej i reasekuracyjnej, ma jednak niewielki walor poznawczy. Bez szerszego kontekstu zaczerpniętego z opracowań naukowych dotyczących tematyki outsourcingu trudno jest określić, czy i w jaki sposób kontrakt outsourcingu różni się od standardowej umowy zlecenia. Istotną kwestią pozostaje również umiejscowienie tej definicji w rozporządzeniach Rady Ministrów będących aktami wykonawczymi do ustawy. Rozporządzenie jako akt prawa doprecyzowuje jedynie przepisy ustawy i nie może kreować nowego rodzaju stosunków zobowiązaniowych. Definicja ta wykazuje więc niewielką przydatność w próbie ogólnego zdefiniowania pojęcia outsourcingu.

\section{DEFINICJE ZACZERPNIĘTE Z LITERATURY}

W celu odnalezienia uniwersalnej definicji outsourcingu lepiej jest posiłkować się koncepcjami wypracowanymi na gruncie literatury przedmiotu. Jednak również tutaj napotkać można ogromną rozbieżność poglądów. W celu zachowania jasności wywodu i usystematyzowania różnorodnych zapatrywań na instytucję outsourcingu, postanowiłam podzielić najważniejsze występujące w literaturze definicje w grupy zbieżnych ze sobą koncepcji.

12 Z dnia 11 września 2015 roku, Dz.U. 2017 roku, poz. 1170, z późn. zm.

${ }_{13} \mathrm{Z}$ dnia 24 grudnia 2007 roku, Dz.U. z 2007 roku, nr 251, poz. 1885, z późn. zm.

${ }^{14} \mathrm{Z}$ dnia 4 września 2015 roku, Dz.U. z 2015 roku, poz. 1676, z późn. zm. 
Pierwsza i najliczniejsza wyróżniona przeze mnie grupa definiuje outsourcing z perspektywy usługobiorcy. W grupie tej znajdują się definicje stworzone przez D. Lei i M.A. Hitta ${ }^{15}$; J. Penca ${ }^{16}$; M. Powera, K.C. Desouzę i C. Bonifaziego ${ }^{17}$ oraz L. Dominguez ${ }^{18}$. Wszystkie one, $\mathrm{w}$ pewnym zakresie, definiują outsourcing jako korzystanie przez firmę - usługobiorcę z usług usługodawcy znajdującego się na zewnątrz, poza strukturą organizacyjną firmy zlecającej. Usługi te polegać mają na wykonywaniu przez usługodawcę na rzecz firmy zlecającej jej zadań.

Kolejna grupa definicji, reprezentowana przez M. Trockiego ${ }^{19}$ oraz K.M. Gille’a i A. Rasheeda ${ }^{20}$ również ujmuje kwestię outsourcingu z punktu widzenia firmy zlecającej, ale w przeciwieństwie do pierwszej grupy kładzie nacisk na fakt, że zadania zlecane firmie outsourcingowej stanowią organizacyjną część firmy zlecającej i pierwotnie znajdowały się w jej strukturze. Zgodnie z tymi poglądami outsourcing jest więc zleceniem wykonywania przez firmę zewnętrzną wydzielonych zadań, pierwotnie realizowanych przez firmę zlecającą lub, według autorów drugiej definicji, również takich, które mogły być, ale nigdy nie były realizowane przez firmę zlecającą w ramach wewnętrznej struktury.

\footnotetext{
${ }^{15}$ Definicja proponowana przez autorów: „Outsourcing refers to the reliance on external sources for manufacturing components and other value-adding activities”,czyli „Outsourcing odnosi się do korzystania przez firmę z zewnętrznych zasobów w zakresie produkcji oraz innych czynności podwyższających wartość" [tłum. własne]; [w:] D. Lei, M.A. Hitt, Strategic Restructuring and Outsourcing: The Effect of Mergers and Acquisitions and LBOs on Building Firm Skills and Capabilities, "Journal of Management"1995, vol. 21, no. 5, s. 836, http://journals.sagepub.com/doi/pdf/10.1177/014920639502100502 [dostęp: 1.12.2017]. ${ }^{16}$ Definicja proponowana przez autora: „Korzystanie z kompleksowych usług będących kombinacją różnorodnych usług cząstkowych sprzedawanych i rozliczanych jako jednostka, jakie oferują zewnętrzni wykonawcy (oferenci)"; [w:] J. Penc, Leksykon biznesu, Warszawa 1997, s. 302.

17 Definicja proponowana przez autorów: „Zlecanie pracy na zewnątrz, czyli komuś, kto znajduje się poza organizacją"; [w:] M. Power, K.C. Desouza, C. Bonifazi, Outsourcing. Podręcznik sprawdzonych praktyk, Warszawa 2008, s. 20.

${ }_{18}$ Definicja proponowana przez autorkę: „Praktyka wynajmowania kompetencji organizacji zewnętrznych w celu zajmowania się przez nią zadaniami i zarządzania zespołami firmy zlecającej, które nie mieszczą się w jej głównym obszarze działalności. Jest to także jedna z metod powiększenia liczebności personelu bez dodawania kogokolwiek do stanu osobowego organizacji"; [w:] L. Dominguez, Outsourcing krok po kroku dla menedżerów, Warszawa 2013, s. 27.

19 Definicja proponowana przez autora: „Przedsięwzięcie polegające na wydzieleniu ze struktury organizacyjnej przedsiębiorstwa macierzystego realizowanych przez nie funkcji i przekazanie ich do realizacji innym podmiotom gospodarczym"; [w:] M. Trocki, Outsourcing: Metoda restrukturyzacji działalności gospodarczej, Warszawa 2001, s. 13.

${ }^{20}$ Definicja proponowana przez autorów: „Outsourcing need not be limited to those [internal] activities that are shifted to external suppliers. On the contrary, outsourcing may also arise when a firm purchases goods or services from outside organizations even when those goods or services have not been completed in-house in the past (...) outsourcing also reflects a decision to reject internalization”, czyli „Outsourcingu nie można ograniczać do sytuacji, kiedy te [wewnętrzne] zadania organizacji zostały przeniesione na zewnętrznego dostawcę. Wręcz przeciwnie, z outsourcingiem mamy do czynienia również, kiedy firma nabywa towary lub usługi od zewnętrznej organizacji w sytuacji, gdy te dobra lub usługi nigdy nie były dostarczane wewnątrz jej struktury w przeszłości (...) outsourcing jest również decyzją o uniknięciu internalizacji zadań" [tłum. własne]; [w:] K.M. Gilley, A. Rasheed, Making More by Doing Less: An Analysis of Outsourcing and its Effects on Firm Performance, „Journal of Management"2000, vol. 26, no. 4, s. 764-765, http://journals.sagepub.com/doi/ pdf/10.1177/014920630002600408 [dostęp: 1.12.2017].
} 
Przeciwny punkt widzenia przyjmują definicje skonstruowane przez M. Pańkowską ${ }^{21}$ oraz M.F. Greavera Jr. ${ }^{22}$ Autorzy ci nakreślają pojęcie outsourcingu z perspektywy firmy outsourcingowej. Dla nich termin ten oznacza wydelegowanie na podstawie umowy zasobów materialnych, ludzkich lub technologicznych na rzecz innego podmiotu z przekazaniem mu kompetencji decyzyjnych dotyczących wydelegowanych środków.

Bardzo interesujące spojrzenie na kwestię znaczenia pojęcia outsourcingu przedstawili K. Lysons i M. Gillinham, twierdząc, że outsourcing to „przeniesienie na stronę trzecią stałej odpowiedzialności menedżerskiej za wykonanie usługi określonej w umowie"23. Taką samą definicję outsourcingu przywołują C.L. Gay i J. Essinger ${ }^{24}$. Po części podobne ujęcie można znaleźć w przedstawionej wyżej definicji autorstwa M.F. Greavera Jr. Zdaniem tego autora w zakres pojęcia outsourcingu wchodzi między innymi przeniesienie kompetencji decyzyjnych, które rozumiane są tu jako odpowiedzialność za dokonywanie decyzji dotyczących przeniesionych zasobów ${ }^{25}$.

Część autorów akcentuje rolę zatrudnienia $\mathrm{w}$ instytucji outsourcingu. Zgodnie z tym podejściem z outsourcingiem mamy do czynienia w sytuacji, gdy pracodawca "A" zawiera umowę $\mathrm{z}$ innym pracodawcą lub pracodawcami, $\mathrm{w}$ celu wykonywania przez pracowników tego pracodawcy lub pracodawców zadań uprzednio wykonywanych przez pracowników pracodawcy „A”26. Takie zapatrywanie, kładące nacisk na transferowanie na podstawie umowy outsourcingu zasobów ludzkich pomiędzy stronami umowy, a więc na rolę i pozycję pracowników w tego rodzaju relacji prawnej między praco-

\footnotetext{
${ }^{21}$ Definicja proponowana przez autorkę: „Oddelegowanie na podstawie umowy kontraktowej całości lub części zasobów materialnych (maszyn, urządzeń), zasobów ludzkich i odpowiedzialności zarządczej do dyspozycji zewnętrznego dostawcy"; [w:] M. Pańkowska, Współdziałanie podmiotów rynku produktów i ustug informatycznych, Katowice 1998, s. 14.

${ }^{22}$ Definicja proponowana przez autora: „Outsourcing is the act of transferring some of an organization's recurring internal activities and decisions rights to outside providers, as set forth in a contract. (...) As a matter of practice, not only are the activities transferred, but the factors of production and decision rights often are, too. Factors of production are the resources that make the activities occur and include people, facilities, equipment, technology, and other assets. Decision rights are the responsibilities for ma king decinions over certain elements of the activities transferred”, czyli „Outsourcing jest czynnością polegającą na przeniesieniu części powtarzających się, wewnętrznych zadań organizacji oraz kompetencji decyzyjnych na zewnętrznych w stosunku do niej dostawców usług, na podstawie kontraktu. (...) W praktyce dochodzi do przekazania nie tylko zadań, ale również czynników produkcji i kompetencji decyzyjnych. Przekazywane czynniki produkcji są środkami, które pozwalaja na wykonywanie zadań i należą do nich: zasoby ludzkie, urządzenia, sprzęt, technologia i inne zasoby. Kompetencje decyzyjne są odpowiedzialnością za dokonywanie decyzji w zakresie konkretnych przeniesionych elementów i czynności” [tłum. własne]; [w:] M.F. Greaver Jr., Strategic Outsourcing. A Structured Approach to Outsourcing Decisions and Initiatives, New York 1999, s. 3.

${ }^{23}$ K. Lysons, M. Gillinham, Purchasing and Supply Chain Management, 2003, s. 351, za: E. Marcinkowska, Outsourcing w zarządzaniu..., s. 10.

${ }^{24}$ C.L. Gay, J. Essinger, Outsourcing strategiczny: koncepcja, modele i wdrażanie, Kraków 2002, s. 12.

25 M.F. Greaver Jr., Strategic Outsourcing..., s. 3.

26 Definicja proponowana przez autora: "Outsourcing occurs when employer A contracts with another employer or employers (including independent contractors) to have the employee of that (or those) other employer(s) do work formerly done by employees of employer A."; [w:] C. Perry, Outsourcing and Union Power, "Journal of Labour Research" 1997, vol. XVIII, no. 4, s. 521, https://link.springer. com/article/10.1007/s12122-997-1020-9 [dostęp: 1.12.2017].
} 
dawcami, jest w mojej ocenie szczególnie przydatne z punktu widzenia prawa pracy ze względu na to, że zwraca ono uwagę właśnie na położenie prawne pracowników oraz na nietypowe dla stosunku pracy ukształtowanie zakresu ich obowiązków pracowniczych.

Definicja ta modyfikuje też nieco zakres przedmiotowy pojęcia outsourcingu w porównaniu z uprzednio przywoływanymi znaczeniami tego terminu. Zgodnie z tym rozumieniem przedmiotem umowy outsourcingu nie są już zadania, procesy czy zasoby, ale praca wykonywana przez pracowników jednego pracodawcy na rzecz drugiego pracodawcy, które to rozumienie wykazuje nieporównywalnie większą funkcjonalność z punktu widzenia prawa pracy i problemów powstających na tym gruncie.

Również zakres podmiotowy omawianej definicji jest ściśle funkcjonalnie powiązany $\mathrm{z}$ dziedziną prawa pracy. Zgodnie $\mathrm{z}$ tym rozumieniem stronami umowy outsourcingu są pracodawcy, którzy umawiają się co do zadań wykonywanych przez pracowników jednego z nich. Definicja ta posługuje się więc kluczowymi pojęciami używanymi w ramach prawa pracy, co niewątpliwie pozytywnie wpływa na możliwość jej stosowania w ramach omawianej gałęzi.

\section{KRYTERIA POZWALAJĄCE WYRÓŻNIĆ UMOWE OUTSOURCINGU}

Outsourcing, zgodnie z zaproponowanym wyżej rozumieniem, jest umową prawa cywilnego zawieraną między pracodawcami. Jej strony oznacza się zazwyczaj jako „zleceniodawcę” i „zleceniobiorcę” lub „usługobiorcę” i „usługodawcę”. Stąd też nasuwa się pytanie, czy i jak należy odróżnić umowę outsourcingu od umowy zlecenia i innych kontraktów cywilnoprawnych. Do tego celu przydatne mogą się okazać kryteria wyróżnione przez J. Foltysa ${ }^{27}$ :

1) Powtarzalność. Outsourcing, jako zadanie wydzielone na zewnątrz, musi cechować się długofalowym i powtarzalnym charakterem. To właśnie długoterminowość decyduje o outsourcingowym charakterze umowy, w przeciwieństwie do jednorazowych zleceń. $Z$ tego też powodu outsourcingiem nie będzie na przykład powierzenie zewnętrznej firmie zadania przeprowadzenia rekrutacji na kilka stanowisk, ale już podpisanie z zewnętrznym podmiotem kontraktu na prowadzenie stałej rekrutacji na większość stanowisk w firmie zlecającej będzie klasyfikowane jako outsourcing ${ }^{28}$.

2) Podmiot usług. O outsourcingu można mówić, gdy usługobiorcą jest pewna organizacja czy podmiot gospodarczy. Trudno mówić o outsourcingu, gdy odbiorcą usług jest osoba prywatna. Na przykład outsourcingiem nie będzie sytuacja, gdy jedna osoba prywatna stołuje się codziennie w tej samej restauracji, ale już wynajęcie firmy cateringowej dla obsługi przedsiębiorstwa i codziennego przygotowywania posiłków dla jego pracowników outsourcingiem będzie.

27 J. Foltys, Wieloaspektowy model..., s. 17-18.

28 J. Marciniak, Optymalizacja zatrudnienia..., s. 173-174. 
3) Pracownicy. Pracownicy świadczący pracę w ramach usługi outsourcingu są zatrudnieni przez podmiot będący dostawcą usług, ale wykonują pracę na rzecz odbiorcy usług. Pracodawca - firma outsourcingowa czerpie więc pośrednią korzyść z pracy wykonywanej przez osoby przez nią zatrudnione. Nie korzysta bezpośrednio z wyników ich pracy, ale uzyskuje korzyść majątkową w związku z zawartą $\mathrm{z}$ usługobiorcą umową outsourcingu.

4) Cel. Wydzielenie części zadań organizacji i powierzenie ich do wykonania podmiotowi zewnętrznemu wiąże się dla przedsiębiorstwa wydzielającego z oczekiwanymi długofalowymi korzyściami. Zazwyczaj celem warunkującym podjęcie decyzji o zastosowaniu outsourcingu są oczekiwane oszczędności majątkowe w połączeniu $\mathrm{z}$ podwyższeniem poziomu profesjonalizmu osób wykonujących dane wydzielone zadanie oraz możliwość skorzystania z zaawansowanej, często drogiej technologii ${ }^{29}$. Wskazuje się również, że podstawowym celem zastosowania outsourcingu jest zwiększenie efektywności procesów wydzielonych na zewnątrz wraz $\mathrm{z}$ jednoczesnym doskonaleniem procesów wewnątrz przedsiębiorstwa ${ }^{30}$.

5) Niezależność podmiotów. Podmioty będące stronami umowy outsourcingu ze względu na przedmiot umowy, jakim jest zlecenie do wykonywania zadań przez podmiot zewnętrzny, muszą być od siebie niezależne na płaszczyźnie prawno-organizacyjnej. Oczywiście nie przeszkadza to powiązaniom kapitałowym między podmiotami. W rzeczywistości częsta jest sytuacja tzw. outsourcingu kapitałowego. Oznacza to, że ze spółki macierzystej wydzielana jest zorganizowana część przedsiębiorstwa wykonująca pewną kategorię zadań i następnie tworzy się spółkę-córkę, która w późniejszym okresie wykonuje te zadania na rzecz spółki macierzystej, na podstawie umowy outsourcingu. Przeciwieństwem outsourcingu kapitałowego jest outsourcing kontraktowy, który polega na wydzieleniu procesów realizowanych przez podmiot i powierzeniu ich do wykonywania innemu, zupełnie niezależnemu i niepowiązanemu z przedsiębiorstwem wydzielającym pomiotowi ${ }^{31}$.

\section{PROPOZYCJA NOWEJ DEFINICJI OUTSOURCINGU NA GRUNCIE PRAWA PRACY}

Na gruncie powyższych rozważań za celową należy uznać próbę sformułowania definicji pojęcia outsourcingu, która okazałaby się wyczerpująca i przydatna z punktu widzenia prawa pracy. W tym celu posłużę się opisanymi już wyżej koncepcjami zaczerpniętymi $z$ literatury przedmiotu.

W mojej opinii na gruncie dziedziny prawa pracy za outsourcing należy uznać taką relację prawną, w której podmiot gospodarczy „A” zawiera umowę z niepowiąza-

29 M.F. Cook, Outsourcing funkcji personalnej, Kraków 2003, s. 22.

30 J. Marciniak, Optymalizacja zatrudnienia..., s. 175.

31 E. Marcinkowska, Outsourcing w zarządzaniu..., s. 15. 
nym z nim na płaszczyźnie prawnoorganizacyjnej podmiotem gospodarczym „B”, będącym jednocześnie pracodawcą, w celu optymalizacji działalności i czerpania długofalowych korzyści gospodarczych przez podmiot „A”, a przedmiotem tej umowy jest stałe i powtarzalne wykonywanie przez pracowników podmiotu „B” zadań wewnętrznych podmiotu „A”, które były lub mogły być przez niego wykonywane samodzielnie.

Ze względu na podkreślane już na wcześniejszym etapie niniejszego opracowania funkcjonalne i pojęciowe związanie z dziedziną praw pracy, za punkt wyjścia do sformułowania powyższej definicji posłużyła mi koncepcja zaproponowane przez C. Perry’ego. Jednocześnie za konieczne uznałam doprecyzowanie tej definicji. W tym celu posiłkowałam się kryteriami wyróżnionymi przez J. Foltysa. Uważam, że zaproponowana przeze mnie definicja nie tylko wykazuje praktyczne powiązanie z dziedziną prawa pracy, zachowując na tym polu wszystkie zalety definicji C. Perry'ego, ale też, w porównaniu $\mathrm{z}$ tą definicją, pozwala na precyzyjniejsze odróżnienie relacji outsourcingu od innych relacji prawnych występujących między podmiotami na rynku gospodarczym. Wobec powyższego uważam, że sformułowana wyżej definicja w sposób najpełniejszy odpowiada obecnym potrzebom dziedziny prawa pracy.

\section{PODSUMOWANIE}

Reasumując powyższe rozważania, należy stwierdzić, że określenie zakresu pojęciowego terminu „outsourcing” nie jest kwestią oczywistą. De lege lata brak jest definicji, której można by nadać przymiot uniwersalności czy kompleksowości zarówno na gruncie prawodawstwa polskiego, jak i unijnego. Również rozważania autorów opracowań $\mathrm{z}$ tego zakresu pozostają rozbieżne $\mathrm{w}$ wielu kwestiach i prezentują często przeciwstawne podejścia do tematu, co może utrudniać zrozumienie znaczenia omawianego pojęcia.

Wybierając definicję outsourcingu, którą można posługiwać się na gruncie prawa pracy, należy mieć na względzie przede wszystkim jej funkcjonalność i możliwość zastosowania w ramach tej dziedziny. $Z$ tego punktu widzenia jako przydatną należy wskazać definicję zaproponowaną przez C. Perry’ego ze względu na jej zakres przedmiotowy i podmiotowy. Ponadto w celu uniknięcia wątpliwości, czy w danym przypadku należy mówić o outsourcingu, można wyszczególnić szereg kryteriów pozwalających odróżnić umowę outsourcingu od standardowych umów zlecenia i innych kontraktów cywilnoprawnych. Mając na uwadze wyżej wskazaną funkcjonalność oraz kryteria charakteryzujące outsourcing, w ostatniej części niniejszego wywodu zaproponowałam nową definicję omawianej relacji prawnej, która może mieć zastosowanie na gruncie polskiego prawa pracy. 


\section{Bibliografia}

\section{Literatura:}

Cook M.F., Outsourcing funkcji personalnej, Kraków 2003.

Dominguez L., Outsourcing krok po kroku dla menedżerów, Warszawa 2013.

Foltys J., Wieloaspektowy model outsourcingu na przykładzie sektora hutnictwa żelaza i stali, Katowice 2007.

Gay C.L., Essinger J., Outsourcing strategiczny: koncepcja, modele i wdrażanie, Kraków 2002. Gilley K.M., Rasheed A., Making More by Doing Less: An Analysis of Outsourcing and its Effects on Firm Performance, "Journal of Management" 2000, vol. 26, no. 4.

Greaver Jr. M.F., Strategic Outsourcing. A Structured Approach to Outsourcing Decisions and Initiatives, New York 1999.

Korzeniowska A., Klasyfikacje outsourcingu, "Annales Universitatis Mariae Curie-Skłodowska" 2009, sectio H, vol. XLIII, 17.

Lei D., Hitt M. A., Strategic Restructuring and Outsourcing: The Effect of Mergers and Acquisitions and LBOs on Building Firm Skills and Capabilities, "Journal of Management" 1995, vol. 21 , no. 5 .

Leighton P., Syrett M., Hecker R., Holland P., Nowoczesne formy zatrudnienia, Warszawa 2014. Marciniak J., Optymalizacja zatrudnienia, wynagrodzeń i struktur organizacyjnych, Warszawa 2016.

Marcinkowska E., Outsourcing w zarządzaniu szpitalem publicznym, Warszawa 2010.

Naruniec T., Outsourcing, [w:] J. Mioduszewski (red.), Metody organizacji i zarzadzania, Olsztyn 2013.

Pańkowska M., Współdziałanie podmiotów rynku produktów i usług informatycznych, Katowice 1998.

Penc J., Leksykon biznesu, Warszawa 1997.

Perry C., Outsourcing and Union Power, "Journal of Labour Research" 1997, vol. XVIII, no. 4. Power M.J., Desouza K.C., Bonifazi C., Outsourcing. Podręcznik sprawdzonych praktyk, Warszawa 2008.

Śliwa N., Bilans outsourcingu - najważniejsze korzyści i straty z wydzielenia działalności, [w:] S. Wawak, M. Sołtysik (red.), Współczesne trendy w outsourcingu, Kraków 2015.

Trocki M., Outsourcing: Metoda restrukturyzacji działalności gospodarczej, Warszawa 2001.

\section{Akty normatywne:}

Dyrektywa Komisji 2006/73/WE z dnia 10 sierpnia 2006 r. wprowadzająca środki wykonawcze do dyrektywy 2004/39/WE Parlamentu Europejskiego i Rady w odniesieniu do wymogów organizacyjnych i warunków prowadzenia działalności przez przedsiębiorstwa inwestycyjne oraz pojęć zdefiniowanych na potrzeby tejże dyrektywy; (Dz.U.UE.L.2006.241.26). Dyrektywa Parlamentu Europejskiego i Rady 2009/138/WE z dnia 25 listopada 2009 r. w sprawie podejmowania i prowadzenia działalności ubezpieczeniowej i reasekuracyjnej (Wypłacalność II); (Dz.U.UE.L.2009.335.1).

Rozporządzenie Rady Ministrów z dnia 24 grudnia 2007 r. w sprawie Polskiej Klasyfikacji Działalności (PKD); (Dz.U. nr 251, poz. 885).

Rozporządzenie Rady Ministrów z dnia 4 września 2015 r. w sprawie Polskiej Klasyfikacji Wyrobów i Usług (PKWiU); (Dz.U. z 2015 r., poz. 1676).

Ustawa z dnia 11 września 2015 r. o działalności ubezpieczeniowej i reasekuracyjnej; (tekst jedn. Dz.U. z 2017 r., poz. 1170). 
Streszczenie: Niniejsze opracowanie stanowi próbę odnalezienia definicji pojęcia „outsourcing”, która byłaby przydatna na gruncie prawa pracy. W tym celu w pierwszej kolejności zostały wskazane przykłady użycia terminu „outsourcing” w prawodawstwie unijnym oraz polskim wraz z oceną ich przydatności przy budowaniu ogólnej definicji pojęcia. Następnie najważniejsze definicje outsourcingu występujące w literaturze zostały podzielone w grupy zbieżnych ze sobą poglądów oraz wskazana została definicja, która ze względu na swój zakres przedmiotowy i podmiotowy wykazuje największą przydatność z punktu widzenia prawa pracy. Na koniec wykazano szereg kryteriów charakteryzujących umowę outsourcingu, które pozwalają na odróżnienie jej od umowy zlecenia oraz zaproponowano nową definicję pojęcia outsourcingu na gruncie prawa pracy.

Słowa kluczowe: outsourcing, umowa outsourcingu, definicja, definicja legalna, prawo pracy, prawo Unii Europejskiej, prawo polskie

\section{OUTSOURCING - AN ATTEMPT TO FIND A DEFINITION OF THE NOTION WITHIN THE SCOPE OF POLISH LABOUR LAW}

Summary: This article constitutes an attempt to find a definition of the notion of 'outsourcing' that would be useful within the scope of Polish labour law. For this purpose, in the first place, the examples of use of the term 'outsourcing' within European Union law and Polish law have been presented along with assessments of those usages from the perspective of usefulness for building a general definition of the notion. Subsequently, the most significant literary definition of the notion have been divided into groups of concurrent views, and a definition that would be the most useful from the perspective of Polish labour law, considering its material and subjective scope, has been suggested. Later, a number of criteria characterising the contract of outsourcing have been indicated. Those criteria would also allow to distinguish a contract of outsourcing from a contract of mandate. As the last step, a new definition of the term 'outsourcing' within the scope of labour law has been proposed.

Keywords: outsourcing, outsourcing contract, outsourcing agreement, definition, legal definition, labour law, UE law, Polish law 